\title{
Competitive and Comparative Advantages Analysis of Organic Rice Farming in Karanganyar Regency, Central Java Province
}

\author{
Anita Suharyati, Slamet Hartono, Lestari Rahayu Waluyati \\ Department of Agricultural Socio Economics, Faculty of Agriculture, Universitas Gadjah Mada \\ Jln. Flora no. 1, Bulaksumur, Sleman, Yogyakarta 55281 \\ *Corresponding email: anitasuharyati14@gmail.com
}

Received: 29th March 2016; Revised: 19 th June 2016; Accepted:23 $3^{\text {rd }}$ January 2017

\begin{abstract}
In era of the free trade which increasingly competitive, it is important to understand the competitiveness of foodstuff commodity by every country. Public awareness of health hazards and adverse environmental impacts, as well as the trend of consumers choosing safe foodstuffs, lead to a shift to the cultivation of organic systems. This paper uses Policy Analysis Matrix (PAM) analysis to determine whether rice farming system has a comparative and competitive advantages when produced with organic farming practices. The purposes of this paper are to (1) Analyse the financial and economic advantages of organic rice farming in Karanganyar. (2) Analyse competitiveness of organic rice in Karanganyar Regency viewed from competitive advantage and comparative advantage. Based on the data analysis, results show that the organic rice farming in Karanganyar Regency has a competitive advantage and comparative advantage, indicated by PCR and DRC value that is less than one. The competitive advantage of organic rice in Karanganyar Regency is greater than the comparative advantage. PCR coefficient amount of 0.74 and DRC coefficient amount of 0.56 . Thus organic rice farming in Karanganyar Regency is worth developing and has good competitiveness in domestic market as well as international market.
\end{abstract}

Keywords: Comparative advantage, Competitive advantage, Organic rice, Policy Analysis Matrix (PAM)

\section{INTRODUCTION}

Trade liberalisation more strengthened provides new opportunities at that time give new challenges that must be faced. In terms of market demand, trade liberalisation provides new opportunities as a result of a broader market in line elimination of trade barriers between countries. However, trade liberalisation also poses serious problems if locally produced commodities are not able to compete in world markets. The existence of free flow of goods and services force manufacturers to focus on the quality of agricultural products. The problems in the aspect of competitiveness of agricultural products include: a) demands standardisation of products and processes, b) demands food that does not contain hazardous materials, c) demands integration of supply chain management, and d) improving the quality of food quality and safety. To answer the challenges of food commodities, development began in earnest with environmental friendly farming methods using organic farming input (Willer, 2010).
Agricultural products should be able to compete and provide a positive value that can be perceived by consumers, both nationally and globally. Agricultural products will not be able to compete if the farming system is not capable of producing quality and safety of agricultural products in accordance with consumers demands. In the era of free markets, agricultural products are required to be able to compete not only in the international market, but also in the domestic market (Mayrowani, 2012).

One of the agricultural products traded in international market is rice. Although up until now Indonesia is a rice importer, it does not deter the possibility of Indonesia from becoming a rice exporter. Indonesia is able to export rice in particular, that is high quality, flavorful and distinctive taste of rice, and organic rice. One of the conditions in exporting rice, by Trade Minister Regulation No.19/M-DAG/PER/3/2014, is that rice has to be produced through an organic farming systems with a breakage rate of $25 \%$. Organic rice 
Table 1. Exports of rice Indonesia, Thailand, and Vietnam Year 2012-2014

\begin{tabular}{cccc}
\hline Period & Export Indonesia & Export Vietnam & Export Thailand \\
\hline 2012 & 1,186 & $3,673,654$ & $4,632,270$ \\
2013 & 1,191 & $1,673,955$ & $4,429,582$ \\
2014 & 759 & $1,800,000$ & $5,400,000$ \\
\hline \multicolumn{2}{l}{ Source: Food and Agriculture Organization (FAO) in 2015}
\end{tabular}

Table 2. Organic Rice Planting Area in Karanganyar 2014

\begin{tabular}{cccccc}
\hline No. & Village & $\begin{array}{c}\text { Harvested Area } \\
\text { (Ha) }\end{array}$ & $\begin{array}{c}\text { Production } \\
\text { (Ton) }\end{array}$ & $\begin{array}{c}\text { Productivity } \\
\text { (Ton/Ha) }\end{array}$ & $\begin{array}{c}\text { Number of Farmers } \\
\text { (Person) }\end{array}$ \\
\hline 1. & Lalung & 55.70 & 418.76 & 7.52 & 47 \\
2. & Bolong & 40.12 & 314.64 & 7.84 & 25 \\
3. & Jantiharjo & 32.18 & 246.99 & 7.68 & 19 \\
4. & Tegalgede & 13.40 & 101.82 & 7.60 & 8 \\
5. & Jungke & 70.60 & 547.15 & 7.75 & 63 \\
\hline & Total & 212.00 & $1,629.36$ & 38.38 & 162 \\
\hline & Average & 42.40 & 325.872 & 7.68 & 32 \\
\hline
\end{tabular}

Source: Department of food crops and horticulture Karanganyar Regency 2015

is used as a commodity to maintain sustainable agriculture without damaging the environment or the natural biota. Organic rice market increased by 5 percent per year, up to 11 billion sales in 2013. The increase is due to the world market demands of organic farming. The world organic trade reached USD \$ 72 billion in 2013 (IFOAM 2015). The demand is there and Indonesia faces prior export competitors, that is Thailand and Vietnam. Both countries are the highest organice rice exporting countries (IFOAM 2015).

One area that consistently practice organic farming in rice cultivation is Karanganyar Regency. In developing this commodity, obstacles and problems have to be solved. The problem faced is how rice can become the main export comodity that can compete in terms of comparative and competitive advantages, in terms of quality, quantity, and level of efficiency of production factors. The purposes of this study are to analyse the level of financial and economic advantages of organic rice farming, as well as the competitiveness viewed from competitive and comparative advantages of organic rice farming in Karanganyar Regency.

\section{MATERIALS AND METHODS}

\section{Method of Collecting Data}

The data collected include primary and secondary data. The primary data collection is conducted by interviewing organic rice farmers, while secondary data are drawn from agencies that are directly related to this research, such as Department of Agriculture, Central Bureau of Statistics, and official website of relevant departments, libraries, and other institutions that can help to data availability. In this paper, budget data (output, sales revenues, and input costs) valued in hectare for the year 2015 are used to represent typical organic rice farms.

\section{Sampling Method}

The research location, determined intentionally (purposive sampling), is in Karanganyar with the consideration of the location is the center of rice production and organic farming systems are consistent and have obtained organic certification from the LSO LESOS. Samples taken from these regency intentionally (purposive sampling) from largest harvested area and most consistently practiced organic farming. District in study site is Karanganyar. The selected village is Jungke village. Respondent conducted using purposive sampling with respondent's criteria are organic rice farmers. The samples are selected from farmer groups PERNIK, with 30 respondents in total.

\section{Data Analysis Method}

Data are analysed using descriptive analysis method and policy analysis matrix. The method of Policy Analysis Matrix (PAM) analysis consists of two identity calculations, that is profitability identity and divergences identity. But in this study, analysis is limited to only count private profits, social benefits, competitiveness with the analysis of comparative and competitive advantage.

From the data in the PAM table 3, data can be analysed using a variety of indicators as follows:

1. Analysis financial Profitability or Private Profitability

Table 3. Policy Analysis Matrix (PAM)

\begin{tabular}{|c|c|c|c|c|}
\hline \multirow{2}{*}{ Elucidation } & \multirow{2}{*}{$\begin{array}{l}\text { Revenue } \\
\text { (Output) }\end{array}$} & \multicolumn{2}{|c|}{ Input Costs } & \multirow{2}{*}{ Profit } \\
\hline & & Tradable & $\begin{array}{c}\text { Non } \\
\text { Tradable }\end{array}$ & \\
\hline Privat Price & $\bar{A}$ & $\mathrm{~B}$ & $\mathrm{C}$ & $\bar{D}$ \\
\hline Social prices & $\mathrm{E}$ & $\mathrm{F}$ & G & $\mathrm{H}$ \\
\hline
\end{tabular}


$(\mathrm{PP}): \mathrm{D}=\mathrm{A}-(\mathrm{B}+\mathrm{C})$

Note:

$\mathrm{D}=$ Profit or advantage based on the actual price (Private Profits / financial).

$\mathrm{A}=$ Revenue (at actual price). Revenue obtained by multiplying the average amount of production per hectare $(\mathrm{kg} / \mathrm{ha})$ multiplied by selling price $(\mathrm{Rp})$.

$\mathrm{B}=$ Input Costs traded (Tradable) based on the actual price.

$\mathrm{C}=$ The cost of domestic factors (Input Costs of non-tradable) based on the actual price. If the negative private profit $(D<0)$, the farmers suffered a loss or not worth the effort. Otherwise, $\mathrm{D}>0$ means organic rice farming feasible to be developed for has an advantage over zero.

2. Analysis of the Profitability economic or social Profitability

(SP): $\mathrm{H}=\mathrm{E}-(\mathrm{F}+\mathrm{G})$

Note:

$\mathrm{H}=$ Profit or advantage based on social price.

$\mathrm{E}=$ Revenue (at social price). Revenue obtained

by multiplying the average amount of production per hectare multiplied by the social price of organic rice.

$\mathrm{F}=$ Cost of inputs that are traded in the international market.

$\mathrm{G}=$ Cost factor (non-tradable input costs) based on social price. If $\mathrm{H}<0$, then the farm is said to be inefficient. Otherwise, $\mathrm{H}>0$ indicates the farm is more efficient and has a high comparative advantage. In general, the concept of efficiency was approached from two sides of the approach of the inputs usage and approaches of the output produced (Coelli, 2005).

3. Financial efficiency (Competitive Advantage) with indicators of Private Cost Ratio:

$\mathrm{PCR}=\mathrm{C} /(\mathrm{A}-\mathrm{B})$.

; Farming has a competitive advantage if the value of PCR is less than 1 . Smaller PCR value means higher competitiveness.

4. Analysis of economic efficiency or comparative advantage indicators Domestic Resource Cost:

$\mathrm{DRC}=\mathrm{G} /(\mathrm{E}-\mathrm{F})$

$\mathrm{DRC}<1$ indicates organic rice farming efficiently or economically viable in the utilisation of domestic resources and DRC $>1$ indicates that activity is inefficient.

The steps are performed in data analysis consists of two stages. The first step is the determination of the input and output as well as input into the identification of the components of tradable inputs are inputs that are traded in the international market both in exports and in imports and the identification of non-tradable inputs are inputs generated in the domestic market and are not internationally traded. The second step is the price of private and shadow prices of input and output, then the tabulation and analysis of indicators resulting in PAM. The interpretation of all entries in the matrices such as private profit, social profit, output, tradable inputs, and domestic factors. Ratio indicators are discussed in the forthcoming section.

\section{RESULT AND DISCUSSION}

\section{Identification of Input and Output and Input Components Grouping Domestic Tradable.}

Inputs included in the non-tradable (domestic) in organic rice farming in Karanganyar Regency are seeds, land, labor, organic fertilisers, and organic pesticides. While, included in tradable inputs are fuel and tool depreciation.

\section{Pricing Shadow}

\section{A. Domestic Input shadow price}

\section{A.1. Land lease}

Rental cost of farmland per year ( 3 planting seasons) at the study site was Rp 24,000,000.- per hectare. Based on Gittinger (1986) statement, the determination of a shadow price of production factors of land is equal to the value of the rent. Thus, the shadow price of agricultural land in the study site per hectare within one is $\mathrm{Rp} 24,000,000$.

\section{A.2. Labor}

Labor shadow price used is based on the assumption of social labor price that is adjusted with the unemployment rate at the sites. Average unemployment in the study site is 18 percent. Thus, the shadow price of labor is 82 percent of the actual labor costs (private).

\section{A.3. Organic Fertilizer and Pesticide Organic}

Organic rice cultivation inputs of fertiliser used are dung, bokashi fertiliser, and liquid organic

Table 4. Identification Component Input Domestic and Foreign

\begin{tabular}{lcc}
\hline Component & Domestic & Foreign \\
\hline Seed & $100 \%$ & $0 \%$ \\
Organic fertilizer & $100 \%$ & $0 \%$ \\
Organic pesticides & $100 \%$ & $0 \%$ \\
Labor costs & $100 \%$ & $0 \%$ \\
Commerce costs & $100 \%$ & $0 \%$ \\
Fuel & $70 \%$ & $30 \%$ \\
Depreciation Tools & $100 \%$ & $0 \%$ \\
\hline
\end{tabular}

Source: * Data Export and Import BPS 2015 
fertiliser that are produced by farmers who are members of a farmer group or purchased from manufacturers around the study site. The shadow price of fertiliser used by farmer of organic rice is equal to the financial price (the price in the market). Organic pesticides shadow price is equal to the price of financial (the price in the market).

\section{B. Shadow Price of Tradable Input}

The equipment used by farmers are hoe, scythe, hand sprayer, sacks, sorok, and water pump. The shadow price of equipment is based on the depreciation per hectare per year. Furthermore, the shadow price of fuel is based on private prices, then calculated the ratio of the increase in fuel prices and the highest retail price plus the cost of distribution to the study site (Manalu, 2015).

\section{C. Shadow Price Currency Exchange Rates}

Determination of the exchange rate is based on the development of the dollar exchange rate. Equilibrium exchange rate can be approximated by using Standard Conversion Factor (SCF) as a correction factor to the official exchange rate applicable (Rosegrant et al., 1987). To determine the shadow price of the exchange rate, a formula by Squire and Van Der Tak (1985) is used as follow,

$$
\mathrm{SCF}=\frac{\mathrm{M}_{\mathrm{t}}+\mathrm{X}_{\mathrm{t}}}{\left(\mathrm{M}_{\mathrm{t}}+\mathrm{TM}_{\mathrm{t}}\right)+\left(\mathrm{X}_{\mathrm{t}}-\mathrm{TX}_{\mathrm{t}}\right)}
$$

Based on the 2015 state budget report issued by BPS, the value of imports is amounted up to $\mathrm{Rp}$ $142,694,804,223$ and an export value of $\mathrm{Rp}$ $150,283,682,737$. Government revenue through import duties of $\mathrm{Rp} \mathrm{37,204} \mathrm{billion} \mathrm{and} \mathrm{government}$ revenue through export tax of $\mathrm{Rp} .14 .3$ billion. The exchange rate of the dollar to the rupiah in 2015 is amounted to $\mathrm{Rp} 13,864$. Once known the value of the SCF, then the SER values obtained with the following formula:

$$
\text { SERT }=\frac{\text { OERT }}{\text { SCFT }}
$$

From the calculation, the obtained value of the standard conversion factor of 2015 (SCF) is 0.927 , so that the value of SER used is Rp 14,947.83.

\section{D. Price Shadow Output}

The shadow price of rice is obtained by subtracting the f.o.b (free on board) price in rupiah with transportation costs, handling costs, and insurance. The fob price for rice is US $\$ 0.73$ per kilogram, then converted with the shadow exchange rate (SER) that

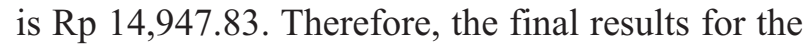
output shadow price is Rp 10,046 per kilogram.

\section{Revenue and Cost Structure of Organic Rice Farming}

Marketing of organic rice output is handled directly by PERNIK farmers group. PERNIK farmers group accommodates all organic rice yields by buying $\mathrm{Rp}$ 4,500, up to 5,000, - per kg dry paddy. With the cooperation of farmer groups, farmers have bargaining power over the sales price of organic rice products. The cooperation is based on the purchase price for one kilogram of organic rice Menthik Wangi variety $\operatorname{Rp} 9,000,-$. The high price of organic rice due to greater use of inputs, limited number of output and quality of rice. Conditions of rice to be sold are pure white, have higher levels of $25 \%$ broken, oval-shaped, and normal rice width.

Total production for organic rice Menthik Wangi variety in one hectare reached 14,085.19 kilograms of rice per year. Average percentage yield research area by $64 \%$. Organic rice farmers plant rice three times a year. One rice season (100-110 days) can produce 7.3-7.5 tons of paddy per hectare. The organic production is higher than conventional rice production.

Total revenues in one year for organic rice Menthik Wangi variety is $\mathrm{Rp} 126,766,681.67$ per hectare. Total revenue earned from one hectare of organic rice cultivation reached $\mathrm{Rp} 33,012,340.18$ per year. Furthermore, in the organic paddy farming the proportion of the cost of input use in organic rice farming can be seen. In Table 4. it can be seen that the highest cost components are additional costs, which up to $41.53 \%$. The high cost of such others are due to the high opportunity costs of land use that is $\operatorname{Rp} 24,000,000 .-$.

\section{Competitiveness Analysis of Organic Rice}

PAM analysis is based on revenues data, costs of production, labor cost, post harvest cost, and cost of depretiation. Additional costs are calculated with financial price (financial analysis) and shadow prices (social analysis). The results of the analysis is in the form of social and financial data on revenues and costs (tradable and non-tradable).

Reception output for organic rice at social prices

Table 5. Proportion of Use of Organic Rice Farming Inputs

\begin{tabular}{lc}
\hline Cost Component Type & Value (\%) \\
\hline Cost of production & 25.56 \\
Labor costs & 22.80 \\
Post harvest costs & 8.34 \\
Cost of depreciation & 1.77 \\
Additional Costs & 41.53 \\
\hline Total & 100 \\
\hline Source: Primary Data Analysis 2016
\end{tabular}


Table 6. Policy Analysis Matrix (PAM) Organic Rice Farming in Karanganyar Regency (Rp/ha).

\begin{tabular}{ccccc}
\hline \multirow{2}{*}{ Elucidation } & \multirow{2}{*}{ Revenue } & \multicolumn{2}{c}{ Input Costs } & \multirow{2}{*}{ Profit } \\
\cline { 3 - 4 } & & Tradable & Non Tradable & \\
\hline Privat Price & $126,766,681.67$ & $648,166.80$ & $93,106,174.69$ & $33,012,340.18$ \\
\hline Social prices & $141,499,787.12$ & $494,166.35$ & $51,087,681.19$ & $89,917,939.59$ \\
\hline Source: Primary Data Analysis 2016
\end{tabular}

is greater than private counterparts. So are the costs incurred both tradable and non-tradable higher social price. So that the financial benefits of organic rice farming in Karanganyar amount of $\mathrm{Rp}$ $33,012,340.18$ and economic profit amount of Rp $89,917,939.59$. From the matrix of policy analysis in Table 6 and then do the calculations that will yield certain values. Those values will be an indicator of the competitiveness of organic rice that is a competitive advantage and comparative advantage.

The competitive advantage of a commodity is determined by the value of private profit (PP) and the Private Cost Ratio (PCR). The prices used in this analysis are the actual prices in the market, where prices are affected by government intervention. The PCR value of organic rice farming in Karanganyar is 0.738. It means that organic rice farming in Karanganyar has a competitive advantage (PCR < 1). Kapaj et al. (2010) stated that the value of PCR $<1$ indicates the manufacturer has positive finacial (private) advantage or has a competitive advantage. PCR value $(0.738)$ indicates that in order to obtain value added output of organic rice farming in Karanganyar regency of one unit in private, the necessary additional domestic factor costs less than one unit is equal to 0.738 . The competitive advantage will increase if domestic factor costs can be minimised or maximise the added value output (Rooyen IM, JF et al., 2001).

Indicators of comparative advantage are the value of social benefits (KS) and the DRC value of organic rice farming in Karanganyar Regency generated by PAM is 0.362 . That is, to produce organic rice in Karanganyar Regency requires a fee of 0.362 percent. Organic rice produced in Karanganyar Regency has competitiveness because it has a

Table 7. Value Competitive Advantage and Comparative Organic Rice Farming in Karanganyar

\begin{tabular}{|c|c|c|}
\hline$\overline{\text { Elucidation }}$ & Unit & Value \\
\hline $\begin{array}{l}\text { Competitive advantage } \\
\text { Private profits }\end{array}$ & $\mathrm{Rp} / \mathrm{ha}$ & $33,012,340.18$ \\
\hline Private Cost Ratio (PCR) & & 0.738 \\
\hline $\begin{array}{l}\text { Comparative Advantage } \\
\text { social advantages }\end{array}$ & $\mathrm{Rp} / \mathrm{ha}$ & $89,917,939.59$ \\
\hline $\begin{array}{l}\text { Domestic Resource Cost } \\
\text { Ratio (DRC) }\end{array}$ & & 0.362 \\
\hline
\end{tabular}

comparative advantage. This means that organic rice farming activities have been streamlined review of aspects of the utilisation of domestic resources available if produced domestically. The smaller the DRC value, the higher the comparative advantage of the commodity. PCR and DRC value less than one indicate that the organic rice cultivation has comparative and competitive advantages. This means that to produce one unit of value-added output in the social price and private price is only required less than one unit cost of domestic resources.

\section{CONCLUSION}

Organic rice farming in Karanganyar Regency is profitable financially and economically with the financial benefits of $\mathrm{Rp} 33,012,340.18$ and economic profit of Rp 89,917,939.59.

Organic rice farming in Karanganyar Regency competitiveness both competitive and comparative advantage because it is efficient in production. The competitive advantage seen from the PCR (Private Cost Ratio) of less than one that is 0.738 . Comparative advantages seen from the DRC (Domestic Resources Cost Ratio) is smaller than one, that is 0.362 .

\section{REFERENCES}

Coelli, T, D.S.P. Rao, C.J. O'Donnell and G.E. Battese. 2005. An Introduction to Efficiency and Productivity Analysis. Second Edition. New York (US): Springer.

FAO. Food and Agriculture Organization. 2015. Export Value Rice 2012-2014.

Gittinger JP. 1986. Analisa Ekonomi Proyek-Proyek Pertanian. Terjemahan. Edisi Kedua. UI-Press dan John Hopkins, Jakarta.

IFOAM Internatinal Foundation for Organic Agriculture Description and Annotated. 2015. The World of Organik Agriculture-Statistic \& Emerging.

Kapaj AM, Kapaj I, Halbrendt CC, Totojani O. 2010. Assesing the Comparative Advantage of Albanian Olive Oil Production. International Food Agribusiness Management Review. International Food Agribusiness Management Association (IAMA).

Mayrowani H. 2012. Pengembangan Pertanian Or- 
ganik. Jurnal : Pusat Sosial Ekonomi dan Kebijakan Pertanian. Jurnal Penelitian Agro Ekonomi. Volume 30 No.2, Desember 2012 :91-108. Bogor.

Monke EA and Pearson ES. 1989. The Policy Analysis Matrix for Agricultural Development. London:.Cornell University Press.

Rooyen IM, J.F. Kirsten, C.J. Van Rooyen. 2001. The Competitiveness of the South African and Australian Flower Industries: an Application of Three Methodologies. Paper presented at the 45th Annual Conference of the 73 Australian Agricultural and Resource Economics Society, January 23 to 25, 2001, Adelaide, South Australia.

Rosegrant MW, Kasryno F, Gonzales LA, Rasahan, and Saefudin Y. 1987. Price and Investment Policies in the Indonesian Food Crop Sektor. International Food Research Institut, Washington D.C and Center for Agro Economic Research. Bogor.

Squire, L. dan H.G. Van der Tak. 1975. Analisis Ekonomi Proyek-Proyek Pembangunan. Penerbit Universitas Indonesia. Jakarta.

Willer H. 2010. Organik Agriculture Worlwide. Key Results from the Global Survey On Organik. Journal Research Institut of Organik Agriculture FiBL and IFOAM, Frick, Switzerland. 